\title{
Unique Capability for Poultry Distributor Companies
}

\author{
Siti Mariam \\ Institut Ilmu Sosial dan Manajemen STIAMI \\ Jakarta, Indonesia \\ Erie Febrian, Mokhamad Anwar, Sutisna \\ Universitas Padjadjaran \\ Sumedang, Indonesia
}

\author{
Budiman Imran \\ Institut Agama Islam Darul Da'wah Wal Irsyad Polewali \\ Mandar \\ Polewali Mandar, Indonesia
}

\author{
Abdul Haeba Ramli* \\ Universitas Trisakti \\ Jakarta, Indonesia \\ *abdul.haeba@trisakti.ac.id
}

\begin{abstract}
The competitive strategy in the poultry distribution corporation in Jakarta indicates low company of innovation management and unique capability. The objective of this investigation is to decide the impact of low company innovation management and unique capability to competitive strategy. Quantitative methods are used in this investigation. Population is the workers of the poultry distribution corporation in Jakarta with more than 2.000 people. Sampling technique used is purposive sampling with the quantity of samples of 104 people. Data collection technique uses questionnaires and regression analysis. Finding on the research results shows that there are positive and significant influence of innovation management on unique capability and positive and significant influence of innovation management on competitive strategy, and also the influence of innovation management on unique capability to competitive strategy.
\end{abstract}

Keywords-competitive strategy, unique capability, management innovation and poultry distribution company

\section{INTRODUCTION}

In some countries, most companies realized the important for innovating to compete in the competition arena in the business world which increasingly shows a very strong rivalry between countries. So that Indonesia also has to make improvements in making the strategy, if it wants to win global business competition. Innovation carried out by organizations is often futile, because success in innovating seems so difficult to predict accurately [1]. Researchers have not provided a valid and reliable theory to make entrepreneurs feel certainly about the business which that the business process will be profitable or not [2].

Most innovation management literature focuses on several specific dimensions of innovation such as market innovation that lead to new customers [3], innovations in technology that lead to products new, or innovation management leads to new processes [4]. However, there are no innovations that can lead them to be able to produce sustainable business for their company [5]. The traditional model of innovation management companies where innovation is considered as a sequential process to transform product launch ideas that focus on technological innovation or product development [6]. The model does not emphasize the needs to simultaneously engage in technological, market and management innovations, and thus fails to provide an opportunity for initial validation of assumptions about customers embedded in business strategies guiding innovation initiatives [7].

This research focuses on the poultry industry to see how management of innovation and competitive strategies in the business. What makes the authors interested in doing research in this field is that consumption of animal foods tends to increase continuously due to the increase in population and income levels, the price of chicken which is relatively cheaper than other meats and the development of other sectors that support chicken farming, for example the opening of new restaurants, restaurants and supermarkets is increasing [8]. Increasingly high public awareness of nutrition fulfillment, increasing community needs at certain times such as wedding parties, and high selling prices during the fasting month, Eid alFitri, Christmas, etc [9]. So that the fulfillment of animal food needs has encouraged the development of businesses in the field of chicken production [10]

One sector that plays a major role in the chicken business is the chicken distributor sector. Chicken distributor is an organization / business that connects suppliers (suppliers) with consumers, serves to integrate so that the two parties are synergistic and can guarantee the accuracy in the distribution of chicken products [11]. In the end it will cause a greater amount of production, compared to the number of requests. With the increase in the amount of production, of course it will have an impact on competition in seizing the market for these products [12]. So that causes every chicken distributor company will do a competitive strategy to maintain and improve the performance of the company. 
In DKI Jakarta Province there are currently 1,153 chicken slaughterhouses, which hav a cutting capacity of 402,000 head / day and 216 locations for chicken shelters, or also called chicken distributor companies and employees as a whole are more than 2,000 people spread in 5 (five) municipalities: Central Jakarta, East Jakarta, South Jakarta, West Jakarta, and North Jakarta, with a chicken holding capacity of 452,460 chicken per day [13]

However, the existing studies have not specifically examined business units in the livestock industry, especially the chicken distributor business unit with a relatively distinctive character of capital and market sources. Therefore, this research will fill the literature gap. Specifically, this investigation will examine the effect of management innovation on competitive strategies through unique capabilities in chicken distributor companies in DKI Jakarta Province.

\section{LITERATURE REVIEW}

\section{A. Innovation Management}

Company innovation is carried out in a company structure or a corporate innovation system consisting of human resources (employees) organizations, activities, resources, institutions and the corporate environment [14]. Employees or organizational members will innovate as a manifestation of their commitment to the company [15-17]. Actors in business transactions, such as customers, employees, and company partners, will participate in activities using company innovation management, by accommodating and seeking ideas or solutions [1]. Institutions such as financial institutions, government institutions, academic institutions and other companies interact with companies that provide resources to facilitate innovation. The interaction between the company and its environment is even more profound in the context of open innovation where companies not only utilize internal resources to drive innovation but also efforts to attract innovative ideas and solutions from the communities in where they operate.

Innovation theory was pioneered by Schumpeter who described innovation as a "creative destruction process" where new products and services were continually created to replace the old [18]. Schumpeter sees innovation as the engine of economic growth and the company with entrepreneurs essentially as agents of economic growth. Then, David expanded innovation theory with his work on the diffusion of innovation [19]. David describes the adoption of new technology as a phenomenon that occurs in five phases (innovators, early adopters, early majority, late majority, and laggards) with each phase facing different users with different tolerance levels for innovation. User distribution follows the normal distribution bell shape with the final majority and final majority representing the main users when innovation is at the peak of adoption.

\section{B. Unique Capability}

Unique capability is defined by Makadok as a specific resource that is owned by the company and invested in increasing the productivity of other resources within the company [20]. Unique capabilities are the strengths and characteristics of the company and its exploitation efforts to encourage companies to create certain products that excel in competition in the market. Unique capabilities related to core capabilities are the company's superior expertise that can provide the greatest benefits to customers [21].

\section{Competitive Strategy}

Business strategies related to how organizations position their business more competitively than other similar industries [22]. Another notion of competitive strategies is stated by Thompson et al., where the competitive strategy of a company relates to game planning from management to compete successfully, namely specific businesses to serve customers, strengthen market position, face maneuvers from competitors, respond to market conditions, and to achieve certain types of excellence [23]. In relation to the company's efforts to be competitive in its market, there are several strategies that can be carried out as stated by Hitt et al [24] that companies can choose five business strategies to build and maintain the company's strategic position against competitors, which consists of: cost of leadership, differentiation, focused cost leadership, focused differentiation, and integrated cost leadership / differentiation.

In relation to the company's efforts to be competitive in its market, there are several strategies that can be carried out as stated by Hitt et al [24] that companies can choose five business strategies to build and maintain the company's strategic position against competitors, which consists of: cost of leadership, differentiation, focused cost leadership, focused differentiation, and integrated cost leadership / differentiation.

\section{HYPOTHESIS DEVELOPMENT}

Innovative Management is the tendency of companies to use and support new ideas, experiments, and creative processes that might succeed in introducing new products or services, new things or technological processes [25]. The results of the research showed the results that the management of Innovations in the typical regional restaurant business in Jabodetabek was able to influence the achievement of the company's unique capabilities, especially in the field of marketing.

Based on various results of the above research, the hypotheses developed in this investigation are:

H1: Management of innovation has a positive and significant effect on unique capabilities.

Wang emphasizes the need to use high-quality workforce, inventions and results of the latest scientific research and technology supporting the latest innovations [26]. This investigation concludes that companies that are competitive 
and quality oriented will have a culture of continuous innovation. The innovation management is related to the use of high-quality workforce and a culture of innovation. So that it can be said that innovation management influences the company's competitive strategy to be able to survive in business competition [26].

Based on various results of the above research, the hypotheses developed in this investigation are:

$\mathrm{H} 2$ : Management of innovation has a positive and significant effect on competitive strategies.

Simonceska underlines that unique capabilities are the strengths and characteristics of the company and its exploitation efforts to encourage companies to create certain products that excel in competition in the market [27]. Unique capability is a superior capacity of a company that can provide the greatest benefits to their customers [21]. Research conducted by Rentala, Anand and Shaban in the Indian industry also supports the conclusions above. Unique capability plays a role in the process of determining competitive strategies [28].

Based on various results of the above research, the hypotheses developed in this investigation are:

H3: Unique capability has a positive and significant effect on competitive strategies.

The findings of Hsieh, Chen, Ming, related to the relationship between resources, unique capabilities and competitive strategies. Competitive strategies are designed based on individual specifications, consistent with human resource strategies, namely skill-oriented strategies and innovations that are the company's unique capabilities [29]. One investigation of the determinants of competitive strategies was carried out by Boasson, who conducted studies on the pharmaceutical industry in the US. In this investigation, Boasson places the characteristics and location of the company as a resource element that affects unique capabilities. The research concludes the important role of unique capabilities for the development of the company's competitive strategy [30].

Based on various results of the above research, the hypotheses developed in this investigation are:

H4: Innovation management has a positive and significant effect for competitive strategies through unique capabilities.

\section{METHODS}

The method used in this investigation is exploratory research with the data sources used in this investigation are primary data covering all respondents who came from chicken distributors in DKI Jakarta Province. The sample is chicken distributor executives from 38 chicken distributor companies in the entire DKI Jakarta Province with a total number of 104 people from more than 2,000 people.

The analysis method starts from looking at the characteristics of the data through descriptive statistics and then the analysis of the multivariate data analysis model includes factor analysis and Partial Least Square (PLS). Because of the limited number of samples used below 200 and the PLS model also does not require data that is not normally distributed [31], besides that this PLS model is a model that is able to explain complex structural models.

The measurement instruments on the three variables in this investigation are for innovation management variables using instruments adopted from [26]. Furthermore, the instrument of the unique capability variable from [21] and competing strategy variables was adopted from [24]. To test the validity of the instrument used the product moment correlation formula proposed by Pearson [32]. Test the validity of innovation management variables, unique capabilities and competitive strategies carried out by validity test as in the table below:

TABLE I. OUTER LOADINGS

\begin{tabular}{|c|c|c|c|}
\hline & $\begin{array}{c}\text { Innovation } \\
\text { Management }\end{array}$ & $\begin{array}{c}\text { Unique } \\
\text { Capability }\end{array}$ & $\begin{array}{c}\text { Competitive } \\
\text { Strategy }\end{array}$ \\
\hline MI1 & 0.6693 & & \\
\hline MI2 & 0.5196 & & \\
\hline MI3 & 0.9761 & & \\
\hline MI4 & 0.8068 & & \\
\hline KU1 & & 0.4102 & \\
\hline KU2 & & 0.6490 & \\
\hline KU3 & & 0.7592 & \\
\hline SB1 & & & 0.9135 \\
\hline SB2 & & & 0.8297 \\
\hline SB3 & & & 0.6289 \\
\hline SB4 & & & 0.5597 \\
\hline
\end{tabular}

In the table 1 above, shows the value of t-value in each indicator of the investigation has good validity. This is based on good validity criteria, where the value of the t-value of each item above is greater than the benchmark value $t$ of 0.3 ( $t$ value> of 0.3) [33]. So, all items are declared valid.

TABLE II. RELIABILITY TEST RESUlts

\begin{tabular}{|l|l|l|l|}
\hline \multicolumn{1}{|c|}{ Variables } & \multicolumn{1}{c|}{$\begin{array}{c}\text { N of } \\
\text { Items }\end{array}$} & $\begin{array}{c}\text { Cronbach's } \\
\text { Alpha }\end{array}$ & Decision \\
\hline $\begin{array}{l}\text { Innovation } \\
\text { Management }\end{array}$ & 4 & 0.772 & Reliable \\
\hline Unique Capability & 3 & 0.814 & Reliable \\
\hline Competitive Strategy & 4 & 0.965 & Reliable \\
\hline
\end{tabular}

Reliability testing is related to the consistency, accuracy, and predictability of a measuring instrument. According to Sekaran and Bougie, the basis for decision making for reliability testing is as follows:

- If the Cronbach's Alpha coefficient is> 0.6, then Cronbach's Alpha is acceptable (reliable construct)

- If Cronbach's Alpha <0.6 then Cronbach's Alpha is poor acceptable (unreliable construct)

From the table 2 above all variables with Cronbach's Alpha are greater than 0.60 , so the variables are considered reliable and this research can be continued [34]. 


\section{RESULTS AND DISCUSSION}

Verifying of the four hypotheses suggested was carried out using Structural Equation Modeling (SEM) with the help of PLS software. Hypothesis test decision making is to look at the results of t-value, where if the value is positive it means that the variable has a positive effect, while to see its significance is to refer to the t-statistic value between variables, if the $t$ value obtained is greater than $\mathrm{t}$-table amounting to 1.96 , meaning that the effect is significant. The results of this investigation, can be seen table 3 below:

TABLE III. HYPOTHESIS TEST RESULTS

\begin{tabular}{|l|l|}
\hline \multicolumn{1}{|c|}{ Variables } & \multicolumn{1}{|c|}{$\begin{array}{c}\text { T Statistics } \\
(\mid \mathbf{O} / \text { STERR })\end{array}$} \\
\hline Innovation Management -> Unique Capability & 1.9851 \\
\hline Innovation Management -> Competitive Strategy & 2.8126 \\
\hline Capability Unique -> Competitive Strategy & 1.2619 \\
\hline $\begin{array}{l}\text { Innovation Management -> Unique Capabilty -> } \\
\text { Competitive Strategy }\end{array}$ & 2.4162 \\
\hline
\end{tabular}

Source: Results of PLS Data

In the table 3 above shows that all the influence between one variable to another variable shows positive values, including:

- The Effect of Innovation Management on Unique Capability is positive and significant because the t-value is 1.9857 which means positive and significant because it is greater than the t-table of 1.96 .

- The influence of Management innovation on competitive strategies is positive and significant because the value of t-value is 2.8126 which means positive and significant because it is greater than t-table of 1.96 .

- Unique capability of influence on competitive strategies is positive but not significant because the value of tvalue is 1.2619 which means positive but not significant because it is smaller than t-table of 1.96 .

- Effect of innovation management on competitive strategies through unique capabilities is positive and significant because the value of t-value is 2.4162 which means positive and significant because it is greater than t-table of 1.96 .

\section{CONCLUSION}

The conclusion of this investigation was formulated based on the results of hypothesis testing. The conclusion of this investigation is that it proved the significant positive influence of innovation management on unique capabilities, then it also proved the positive and significant influence of management innovation on competitive strategies, then also proved a positive but not significant effect of unique capabilities on competitive strategies. And also proved the positive and significant influence of management innovation on competitive strategies through unique capabilities.

\section{MANAGERIAL IMPLICATIONS}

The results of the conclusions above, will provide references to company leaders because the results of this investigation indicate that competitive strategies will be increased positively and significantly if the management of innovation by the company is high and the company's unique capabilities are considered. So that the company will be able to achieve the desired goals and can compete continuously or sustainable.

\section{LIMITATIONS OF RESEARCH AND SUGGESTIONS}

This research was only carried out on employees of a chicken distributor business in Jakarta, so the results could not be generalized to all business industries. And this investigation only examines the management of innovation, competitive strategies, and unique capabilities, so it is necessary to try the development of other variables as determinants of forming competitive strategies, such as technology adoption and management of innovation $[35,36]$.

\section{REFERENCES}

[1] L. Tchuta and F. Xie, "Towards a synergic innovation management model: the interplay of market, technology, and management innovations," Int. J. Bus. Econ. Dev., vol. 5, no. 1, 2017.

[2] C. Christensen, The innovator's dilemma: when new technologies cause great firms to fail, Harvard Business Review Press, 2013

[3] H. Kjellberg, F. Azimont, and E. Reid, "Market innovation processes: Balancing stability and change," Ind. Mark. Manag., vol. 44, pp. 4-12, 2015.

[4] J. Birkinshaw, G. Hamel, and M. J. Mol, "Management innovation," Acad. Manag. Rev., vol. 33, no. 4, pp. 825-845, 2008.

[5] B. Imran and A. H. Ramli, "Kepuasan Pasien, Citra Rumah Sakit dan Kepercayaan Pasien di Provinsi Sulawesi Barat," in Prosiding Seminar Nasional Pakar, 2019, pp. 2-48.

[6] T. Takaya, A. H. Ramli, and N. Lukito, "The effect of advertisement value and context awareness value on purchase intention through attitude brands and advertising attitude in smartphone advertising," Int. J. Creat. Res. Stud., vol. 3, pp. 106-118, 2019.

[7] L. Tchuta and F. Xie, "Towards a synergic innovation management model: the interplay of market, technology, and management innovations,” Int. J. Bus. Econ. Dev., vol. 5, no. 1, 2017.

[8] S. Mariam, "Kepentingan Kebijakan Pembuatan Peraturan Daerah Provinsi Daerah Khusus Ibukota (Dki) Jakarta No. 4 Tahun 2007 (Pengendalian, Pemeliharaan Dan Peredaran Unggas) Dan Implikasinya Terhadap Usaha Pendistribusian Unggas Di DKI Jakarta," J. Reformasi Adm. J. Ilm. untuk Mewujudkan Masy. Madani, vol. 3, no. 1, pp. 107 125, 2016.

[9] Pusat Data dan Sistem Informasi Pertanian (PDSIP), Sekretariat Jenderal Kementerian Pertanian, 2016. Outlook Daging Ayam : Komoditas Pertanian Subsektor Peternakan.

[10] S. Mariam and A. H. Ramli, "Lingkungan Bisnis, Kapabilitas Unik dan Strategi Bersaing Perusahaan Distributor Ayam di Provinsi DKI Jakarta," in Prosiding Seminar Nasional Pakar, 2019, pp. 2-42.

[11] S. Mariam and A. H. Ramli, "Determinan Kinerja Perusahaan pada Distributor Unggas di Provinsi DKI Jakarta," in Prosiding Seminar Nasional Cendekiawan, 2017, pp. 413-417.

[12] A. H. Ramli, "Person-Organization Fit dalam Rantai Distribusi Pemasaran," J. Manaj. dan Pemasar. Jasa, vol. 12, no. 1, pp. 77-92, 2019. 
[13] Dinas Ketahanan Pangan Kelautan dan Pertanian (DKPKP) Provinsi DKI Jakarta, Laporan Tahunan, Dinas Ketahanan dan Pertanian Provinsi DKI Jakarta, 2018.

[14] I.A. Zarqan and S. Sukarni, "Human resource development in the Era of technology; Technology's implementation for innovative human hesource development," J. Manaj. Teor. dan Ter. J. Theory Appl. Manag., vol. 10, no. 3, pp. 217-223, 2017.

[15] A.H. Ramli, "Organizational Commitment And Employee Performance At Distributor Companies," Business And Entrepreneurial (BER), vol. 11, no. 2, pp. 121-134, 2017.

[16] A.H. Ramli and E.T. Maniagasi, "Kinerja Karyawan RSUD DOK II di Jayapura," in Prosiding Seminar Nasional Cendekiawan, 2018, pp. 805810.

[17] A.H. Ramli and R. Yudhistira, "Pengaruh Pengembangan Karir terhadap Kinerja Karyawan melalui Komitmen Organisasi pada PT. Infomedia Solusi Humanika di Jakarta," in Prosiding Seminar Nasional Cendekiawan, 2018, pp. 811-816.

[18] J. Schumpeter, Theory of Economic Development (Social Science Classics Series) Paperback - January 7, 1981. Routledge; New edition edition (December 31, 1980), 1980.

[19] F.R. David, Strategic Management, Concepts \& cases, England: Pearson Education Limited, 2013.

[20] R. Makadok, "Toward a synthesis of the resource-based and dynamic-capability views of rent creation," Strateg. Manag. J., vol. 22, no. 5, pp. 387-401, 2001.

[21] T.L. Wheelen, J.D. Hunger, A.N. Hoffman and C.D. Bamford, "Strategic Management and Business Policy: Globalization, Innovation, and Sustaibility," 14 th, Global Edition, Pearson, 2015.

[22] G. Hubbard and P. Beamish, Strategic Management-Thinking, Analysis, Action, Pearson Australia, 4 th Edition, 2011.

[23] A. Thompson, M. Peteraf, J. Gamble, A.J. Strickland III, and A.K. Jain 2014, Crafting and Executing Strategy, The Quest for Competitive Advantages, Concepts and Cases, Nineteenth Edition, McGraw Hill Education.

[24] M.A. Hitt, R.D. Ireland, and R.E. Hoskisson, Strategic management: Concepts: Competitiveness and globalization. Nelson Education, 2014.
[25] I.H. Hatta, "Analisis pengaruh inovasi, pengambilan resiko, otonomi, dan reaksi proaktif terhadap kapabilitas pemasaran UKM kuliner daerah di Jabodetabek,” J. Manaj. Pemasar., vol. 8, no. 2, pp. 90-96, 2014.

[26] Y. Wang, G. Berens, and C.B.M. Van Riel, "Competing in the capital market with a good reputation," Corp. Reput. Rev., vol. 15, no. 3, pp. 198-221, 2012.

[27] L. Simonceska, "The changes and innovation as a factor of competitiveness of the tourist offer (The Case of Ohrid)," ProcediaSocial Behav. Sci., vol. 44, pp. 32-43, 2012.

[28] S. Rentala, B. Anand, and M. Shaban, "Determinants of Export Performance: New Evidence from Indian Industries," TSM Business Review; Madurai, vol. 2, Iss. 1, pp. 1-17, 2014.

[29] Y.H. Hsieh and H.M. Chen, "Strategic fit among Business Competitive Strategy, Human Resource Strategy, and Reward System.," Acad. Strateg. Manag. J., vol. 10, no. 2, 2011.

[30] V. Boasson and A. MacPherson, "The role of geographic location in the financial and innovation performance of publicly traded pharmaceutical companies: empirical evidence from the Untied States," Environ. Plan. A, vol. 33, no. 8, pp. 1431-1444, 2001.

[31] C. Cassel, P. Hackl, and A.H. Westlund, "Robustness of partial leastsquares method for estimating latent variable quality structures," J. Appl. Stat., vol. 26, no. 4, pp. 435-446, 1999.

[32] S. Arikunto, Prosedur Penelitian Suatu Pendekatan Praktik. Jakarta: Rineka Cipta, 2016.

[33] Sugiyono, Metode Penelitian Kuantitatif, Kualitatif, dan R\&D. Bandung : Alfabeta, CV, 2017.

[34] Sekaran, Uma dan Bougie, R. 2017. Metode Penelitian untuk Bisnis Pendekatan Pengembangan-Keahlian. Jakarta. Salemba Empat.

[35] K. Deng, Three Empirical Studies on Digital Innovation Management: New Organizing Logic of Antecedents and Consequences of Innovation. University of Arkansas, ProQuest Dissertations Publishing, 2018. 13421419.

[36] S. Nambisan, K. Lyytinen, A. Majchrzak, and M. Song, "Digital Innovation Management: Reinventing innovation management research in a digital world.," Mis Q., vol. 41, no. 1, 2017. 